\title{
Assessment of cryospheric parameters over the Himalaya and Antarctic regions using SCATSAT-1 enhanced resolution data
}

\author{
Sandip R. Oza ${ }^{1, *}$, Rajashree V. Bothale ${ }^{2}$, D. Ram Rajak ${ }^{1}$, P. Jayaprasad ${ }^{1}$, \\ Saroj Maity ${ }^{1}$, Praveen K. Thakur ${ }^{3}$, Naveen Tripathi ${ }^{1}$, Arpit Chouksey ${ }^{3}$ and \\ I. M. Bahuguna ${ }^{1}$
}

${ }^{1}$ Space Applications Centre, ISRO, Ahmedabad 380 015, India
${ }^{2}$ National Remote Sensing Centre, ISRO, Hyderabad 500037 , India
${ }^{3}$ Indian Institute of Remote Sensing, ISRO, Dehradun 248001 , India

Antarctica is the focus of scientific studies considering the largest reservoir of terrestrial water in the form of ice and doubling of ice area during winter due to sea-ice growth. The third pole - Himalaya is equally important due to the large extent of snow and ice cover outside the polar regions, which is a major source of water for the Asian countries. At present, the Ku-band scatterometer observing global cryosphere is the SCATSAT-1 launched by India. This article describes the study carried out on different cryospheric parameters using high-resolution $(\sim 2.2 \mathrm{~km})$ scatterometer data in the Antarctica and Himalaya. Impact of seasonal variations in snow/ice and ice calving on the backscatter over Antarctica is discussed in detail. A procedure developed for the estimation of sea-ice extent, which yielded overall accuracy of $89 \%$, has been presented and successfully applied for daily monitoring of the Antarctic ice extent for 2017.

Keywords: Calving, scatterometer, sea-ice, snow water equivalent, surface melt.

\section{Introduction}

THE cryosphere, comprising snow, glaciers, ice sheets, ice shelves, frozen ground and ice over river, lake, sea, plays a major role in the Earth's climate system through its impact on the global atmospheric and oceanic circulation and sea level ${ }^{1}$. Warming Antarctic is dangerous for the Earth's climate, as it holds $70 \%$ of the Earth's freshwater in the form of ice sheets. Moreover, Antarctic cryosphere area doubles during winter due to increased sea-ice growth. Sea ice is an important polar cryospheric element that indicates the polar response to climate change $^{2}$. Information on sea-ice parameters is of immense use in maritime navigation and coupled ocean-iceatmosphere numerical modelling ${ }^{3}$. The Antarctic sea-ice extent has been slowly increasing ${ }^{4}$; overall, however increase in ice extent is highly significant only in the

\footnotetext{
*For correspondence. (e-mail: sandipoza@sac.isro.gov.in)
}

Surface melting using backscatter and brightness temperature data has been discussed and the contrast between large-sized and small-sized Antarctic ice shelves during the austral summer period of summer 2017-18 is highlighted. The higher average surface melt observed around majority of east Antarctic ice shelves, particularly near the Indian station 'Maitri', is of particular interest. Typical surface melting patterns observed over the third largest Antarctic ice shelf, Amery, are discussed in detail. Over northwest Himalaya, derived changes in snow water equivalent $(\triangle \mathrm{SWE})$ shows a good correlation between observed and calculated SWE variations. The present study demonstrates that simultaneous availability of high-resolution brightness temperature and backscatter data from SCATSAT-1 provides a unique opportunity to study the polar and mountain cryosphere.

Ross Sea ${ }^{5}$. Sea-ice trends over the Antarctic show regional anomalies ${ }^{6}$. Antarctic climate is changing and facing warming trend with regional variabilities ${ }^{7}$.

Antarctic ice sheet surface melting can regionally influence ice-shelf stability, mass balance, and glacier dynamics, in addition to modulating near-surface physical and chemical properties over wide areas ${ }^{8}$. Ice shelves over western Antarctica show consistent surface melting and East Antarctic ice shelves are prone to warming ${ }^{8-11}$. Hence continuous monitoring of Antarctic ice is a key component to understand climate change and the only viable tool for continuous monitoring is the utilization of microwave remote sensing data due to its cloud penetration and all-season observation capabilities.

For countries like India, mountain water resources have become increasingly important, with changing climate scenarios. Snowmelt normally constitutes a major part of the total run-off in the mountainous regions ${ }^{12}$. Snow water equivalent (SWE) is a common snowpack measurement used in many hydrological applications to characterize snow cover. SWE is a direct function of snow depth (SD) and snow density $(\rho)$, and represents the 
amount of water stored within a snow pack ${ }^{13}$. Retrieval of SWE from satellite measurements is a challenging task, especially in mountainous terrains due to the complex topography, frequent snow freezing and melting processes, and large spatial variability at the sample sites ${ }^{14}$.

Passive microwave radiometer data ${ }^{15-19}$ and scatterometer data ${ }^{20,21}$ have been utilized for the monitoring of surface snowmelt over Antarctic ice shelves. Since the last 40 years, passive microwave radiometer data are available and have been widely used to monitor the seaice status and its changes ${ }^{22-31}$. Scatterometer data have shown its potential in delineating the sea-ice extent ${ }^{32-35}$. The scatterometer launched by India was utilized for seaice monitoring ${ }^{33,36}$. It was suggested that combining data from both active and passive sensors can improve the performance of multiyear (MY) and first year (FY) ice classification $^{37}$.

The present study focuses on simultaneous utilization of high-resolution brightness temperature (BT) and backscatter data from SCATSAT-1 for seasonal and annual monitoring of Antarctic sea-ice, surface melt over ice shelves and detecting changes around the ice margin. The discussion also covers the outcome of SWE analysis carried out over Northwest Himalaya.

\section{Methodology and data used}

SCATSAT-1 high-resolution $(\sim 2.2 \mathrm{~km})$ sigma-0 $\left(\sigma^{0}\right)$, gamma-0 (Gm) and BT level-4 (L4) data products (http://www.mosdac.gov.in) were utilized in the present study. Temporal response from the various Antarctic cryospheric targets to SCATSAT- $1 \sigma^{0}$, gamma-0 and BT data were examined to understand the target characteristics.

\section{Antarctic sea-ice cover}

Researchers suggested that combining data from both active and passive sensors can improve the performance of MY and FY sea-ice classification ${ }^{37}$. This study has utilized the SCATSAT-1 high-resolution $(\sim 2.2 \mathrm{~km})$ gamma-0 and BT temperature data for determining the sea-ice extent. Response of water and sea-ice is different in $H H$ and $V V$ polarization ${ }^{32,33}$ and hence polarization difference was utilized in sea-ice discrimination against open sea water. Parameter thresholding technique was used in the sea-ice determination process (Figure 1).

As shown in Figure 1, the digital number (DN), was converted into units of gamma-0 (dB) and BT (K). HH and $V V$ represent the $H H$ and $V V$ polarization respectively. NDGI and NDBI are gamma- 0 and BT normalized polarization difference indices. NDBI is the BT normalized polarization difference index. 'Antarctic mask' is the Antarctica land ice mask (including ice shelves) and SIOP36 is the sea-ice occurrence probability ${ }^{38}$.
The changes in the above variables over the study period (January-December 2017) were statistically analysed and bimonthly conservative threshold values were determined for developing an ice extent algorithm. The derived extents were validated against the ice extents obtained from passive microwave-derived sea-ice concentration products from AMSR2 data. As a validation exercise, we compared the SCATSAT-1 estimated ice extents with those obtained by setting a cut-off to the passive microwave-derived ice concentrations-AMSR2 (available from ARTIST sea-ice algorithm at http:// seaice.uni-bermen.de/sea-ice-concentration/).

\section{Antarctic ice shelf surface melt}

Snow is an inhomogeneous medium consisting of ice particles, air and liquid water (if wet). The presence of liquid water in wet snow increases the permittivity of the snow layer ${ }^{39}$. Hence presence of moisture content in and over the snow pack alters the surface emission and backscatter response. In case of wet snow, surface scattering dominates over volume scattering. In addition, presence of liquid water in snow volume causes a dramatic increase in the dielectric loss factor of the layer, which increases absorption coefficient and reduces penetration depth. During summer, penetration depth reduces to the uppermost 3-4 cm (ref 17). This in turn results in a decrease in the backscatter values.

Temporal reduction in backscatter (TRB) is attributed to the summer melting of snow/ice over the icy surface ${ }^{40}$. This fact has been utilized for the monitoring of seasonal

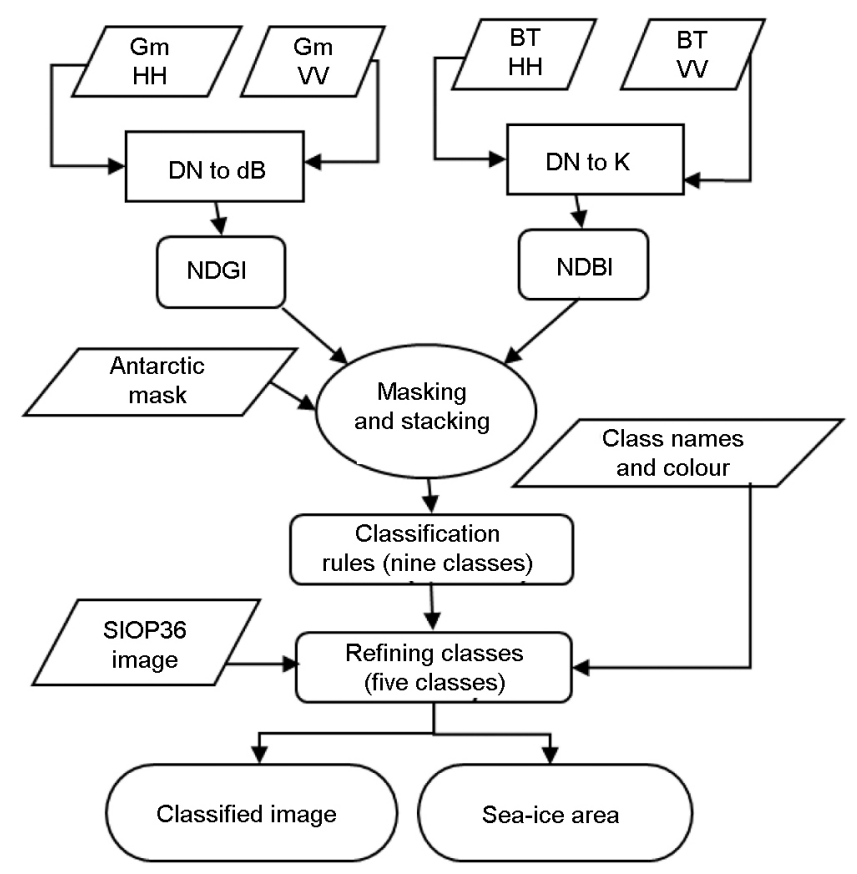

Figure 1. Flow diagram showing procedure for determination of sea ice. 
snowmelt over Greenland with ERS scatterometer data ${ }^{41}$. Researchers have demonstrated the use of TRB approach in monitoring the surface melt of Antarctic ice shelves ${ }^{9,42}$. In the present study, we have analysed surface melt variations using two different datasets, viz. $\sigma^{0}$ backscatter data and BT data.

Melt detection using backscatter data: Based on the austral mean, standard deviation and drop in $\sigma^{0}$ for austral summer, due to the spatial variability in $\sigma_{H H}^{0}$, an adaptive threshold-based classification technique is used to identify melt/freeze over the continent. A melt grid (MG) is identified by satisfying the criteria

$$
\begin{aligned}
& \text { If } \sigma_{H H n}^{0}<\left(\sigma_{H H \text { Mean }}^{0}-\left(2 * \sigma_{H H S \text { max }}^{0}\right)\right) \text {, then } \mathrm{MG}=\text { True, } \\
& \text { If } \sigma_{H H n}^{0} \geq\left(\sigma_{H H \text { Mean }}^{0}-\left(2 * \sigma_{H H S D \text { max }}^{0}\right)\right) \text {, then MG }=\text { False, }
\end{aligned}
$$

where $\sigma_{H H n}^{0}$ is the $H H$ backscatter for the $n$th day, $\sigma_{H H \text { Mean }}^{0}$ is the winter mean and $\sigma_{H H S D \max }^{0}$ is the maximum standard deviation of austral winter $H H$ backscatter for the study area. An adaptive threshold helps in capturing the backscatter characteristics of an individual grid due to its location in the ice-shelf area. Analysis was carried out for the summer period of 2017-18. Winter mean was calculated using May-July data of 2017.

To study shelf-wise variability in the melt, melt index (MI) is calculated, which is defined as

$$
\mathrm{MI}=\sum_{i=1}^{n}(A * M D i)
$$

where $A$ is the grid size, MDi is the number of melt days for the grid and $n$ is total number of grids. MI helps in studying interannual variability in melt over different areas. The summation of MI is computed for the austral summer between November and February.

Melt detection using BT data: The TRB concept has been utilized in the present study, but rather than using backscatter we have employed BT (of $H$ component) data for the derivation of average melt intensity (AMI), which is defined as:

$$
\begin{aligned}
& \mathrm{AMI}=\left(\sum D_{i}\right) / \mathrm{MD}, \\
& D_{i}=\left(\mathrm{BT}_{\mathrm{w} H}-B T_{\mathrm{si}}\right),
\end{aligned}
$$

where $\mathrm{BT}_{\mathrm{si}}$ is the horizontally polarized $\mathrm{BT}_{\mathrm{H}}$ value for the $i$ th day, starting from 1 November 2017 to 28 February 2018. AMI represents the melting index $(\mathrm{K})$, which is the cumulative effect of melting from the beginning of November. $\mathrm{BT}_{\mathrm{w} H}$ is the average $\mathrm{BT}_{H}$ for the peak winter month of June 2017. AMI is the summation of daily differences $\left(D_{i}\right)$ between BT of any day $i$ and the average winter BT for all $D_{i}$ values greater than threshold value $T_{\mathrm{c}}$. This can be considered as an indicator of the magnitude of surface melting during the austral summer period. In this algorithm, $T_{\mathrm{c}}$ is the critical limit of BT difference. Spatio-temporal analysis was carried out to derive $T_{\mathrm{c}}$ and the value was $10 \mathrm{~K}$. The melt day (MD) is defined for those days with $D_{i}$ greater than the value of $T_{\mathrm{c}}$.

We have derived the total number of melt days and AMI for the summer period of November-December-

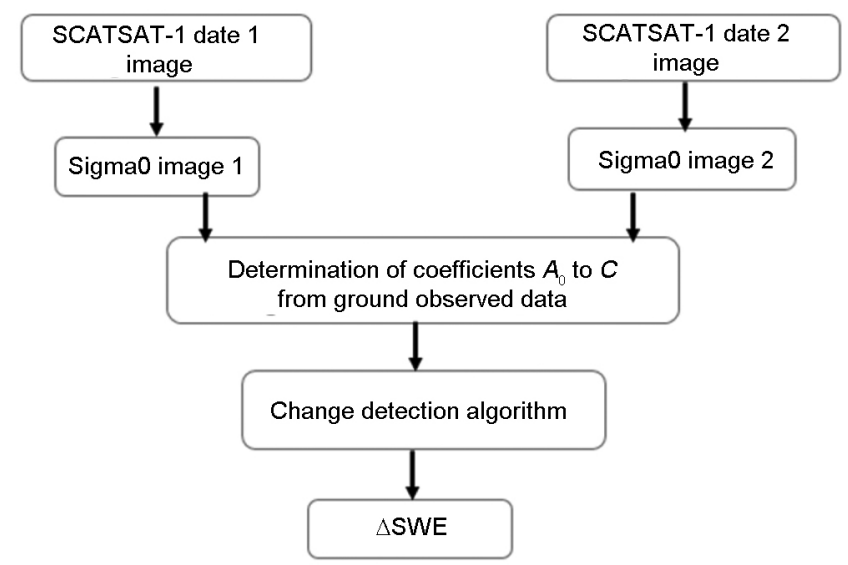

Figure 2. Methodology for snow water equivalent (SWE) change detection algorithm ${ }^{37}$.

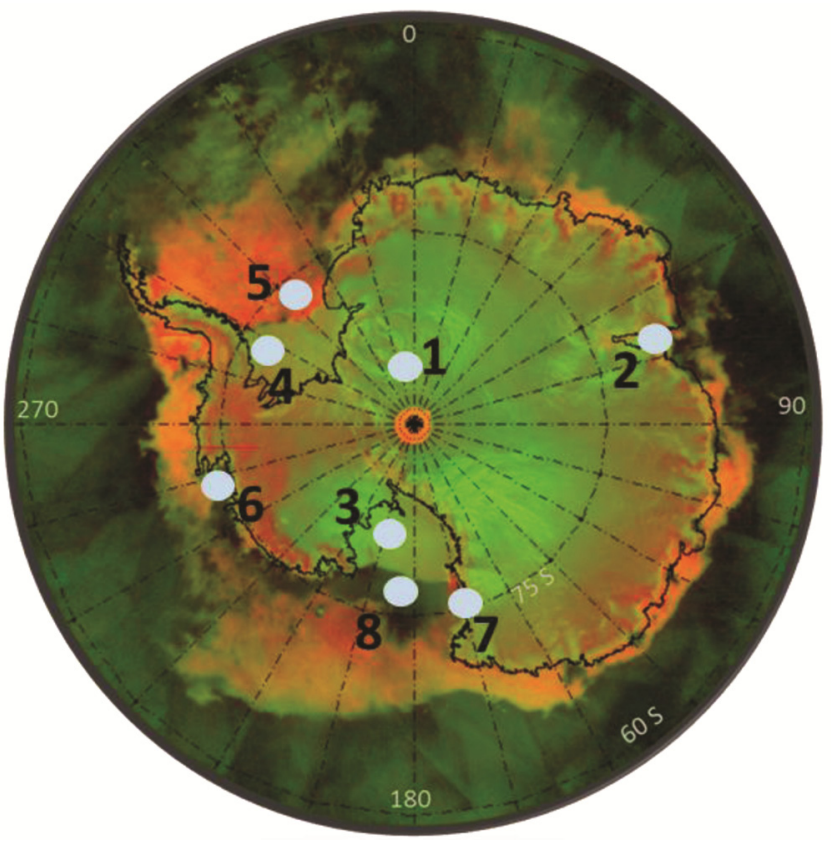

Figure 3. RGB image combination with $\mathrm{BT}(H H)$ in red; gamma$0(V V)$ in green active polarization ratio (APR)-Gamma-0 in blue planes. Labelled features are: (1) sp-icesheet; (2) Amery ice-shelf; (3) Ross ice-shelf; (4) Ronne ice-shelf; (5) iceberg; (6) polynya; (7) glacier and (8) Sea ice-coast. 

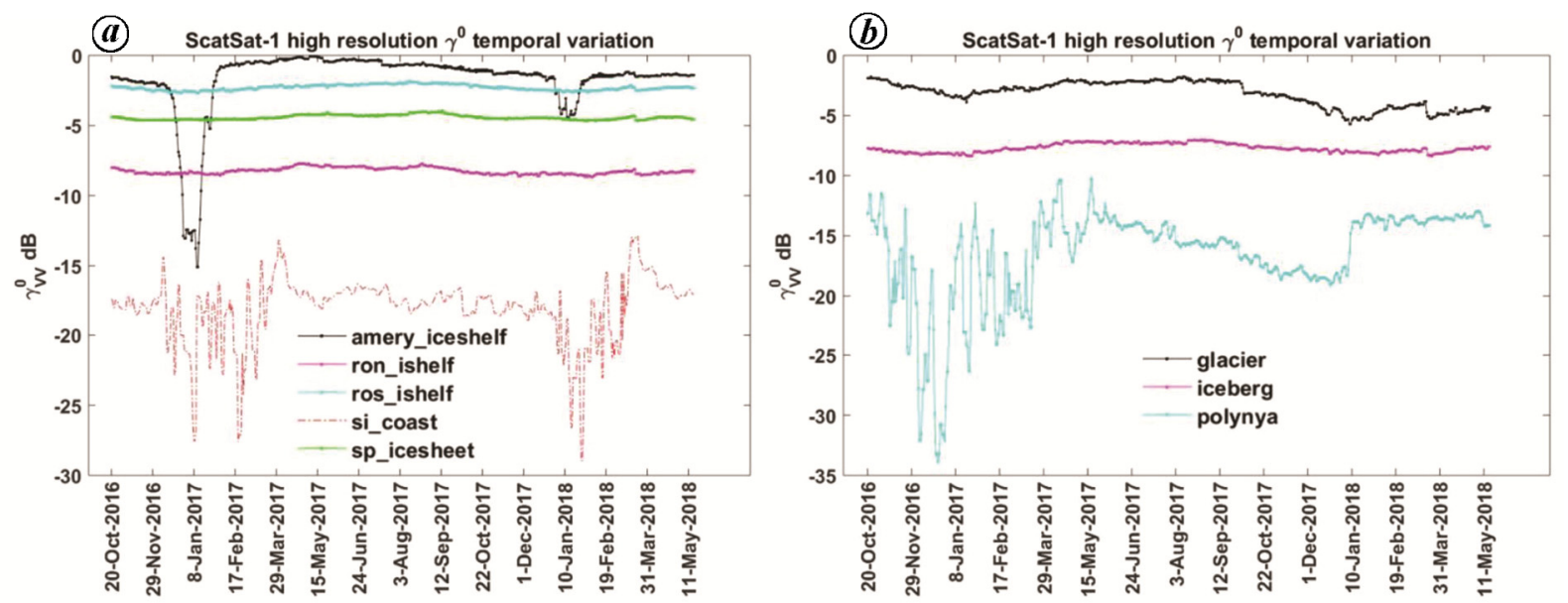

Figure 4. Temporal variations in gamma-0 values $(H H)$ over different polar ice features in the Antarctic.

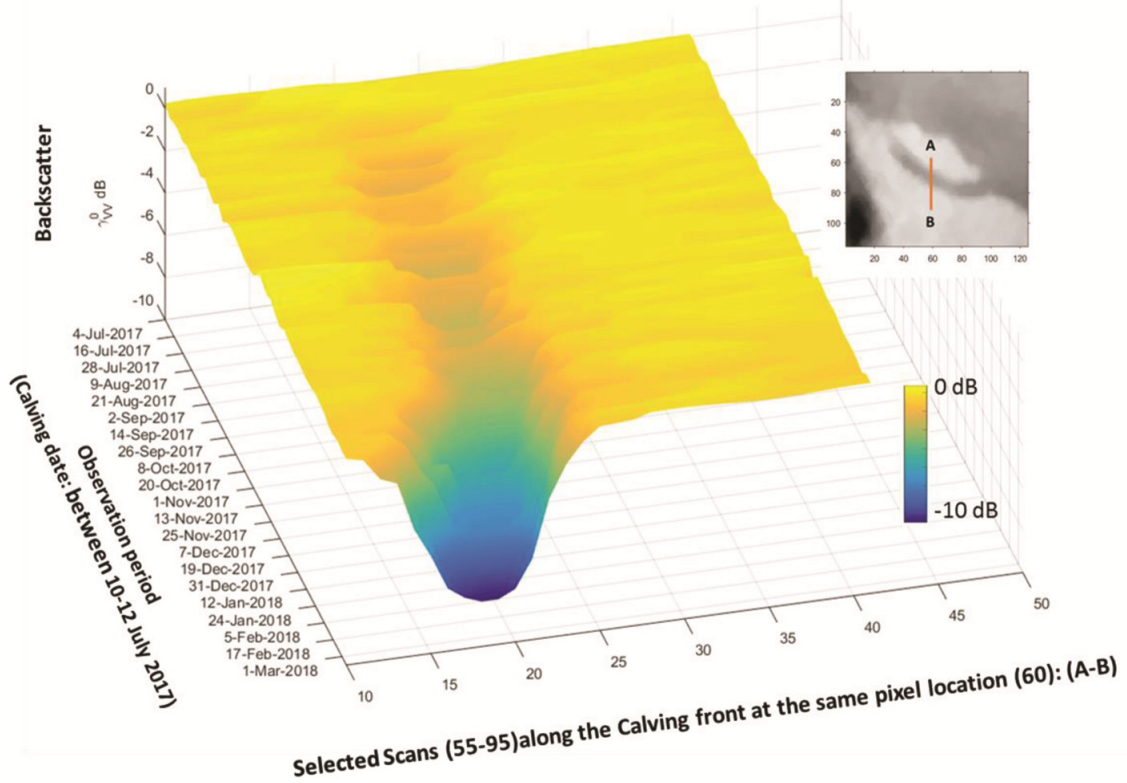

Figure 5. Temporal variations in gamma- 0 values along the transect line $(A B)$ at pixel location 60 and scan lines from 55 to 95 (inset) in the Larsen C shelf.

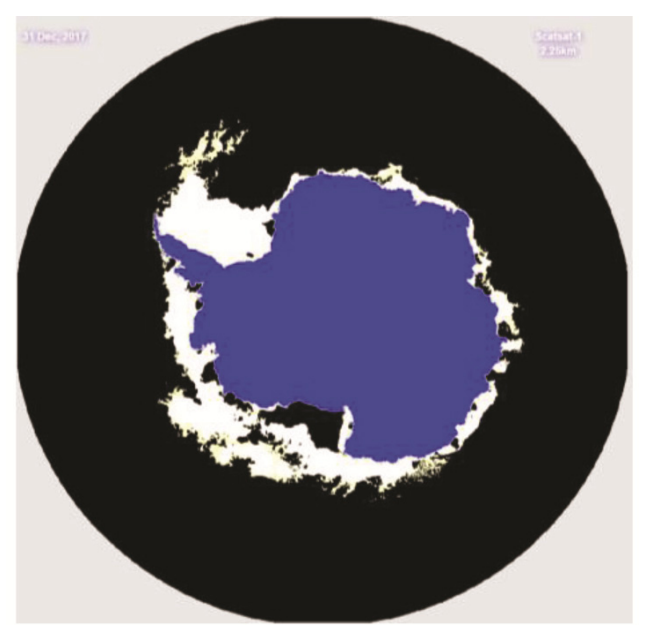

Figure 6. Sea-ice cover around Antarctica on 31 December 2017. Ice sheet mask is shown in blue and black colour shows non-sea-ice area (available on www.vedas.gov.in).
January (2017-18) for all the pixels over ice shelves. MODIS-derived ice-shelf mask was utilized.

\section{Estimation of snow water equivalent in the Himalaya}

The change detection technique was applied for retrieving the change in SWE from the temporal change of SCATSAT-1 backscatter data ${ }^{43}$. We used a one-layer radiative transfer model with several parameters, characterizing the scattering properties of snowpack ${ }^{37}$.

$$
\sigma^{0}=A_{0}-\left(A_{0}-\sigma_{\mathrm{g}}^{0}\right) \exp (-C \cdot \mathrm{SWE})
$$

where $\sigma^{0}$ is the backscattering coefficient. The unit of $A_{0}$ is $\mathrm{LM}^{-3}$, while $C$ is the normalized attenuation parameter; 


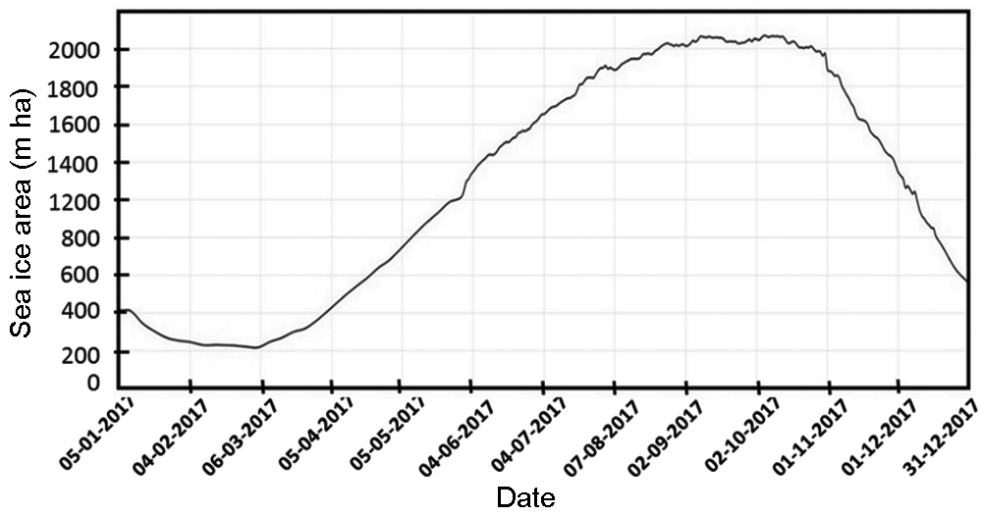

Figure 7. Profile of daily sea-ice extent derived for 2017

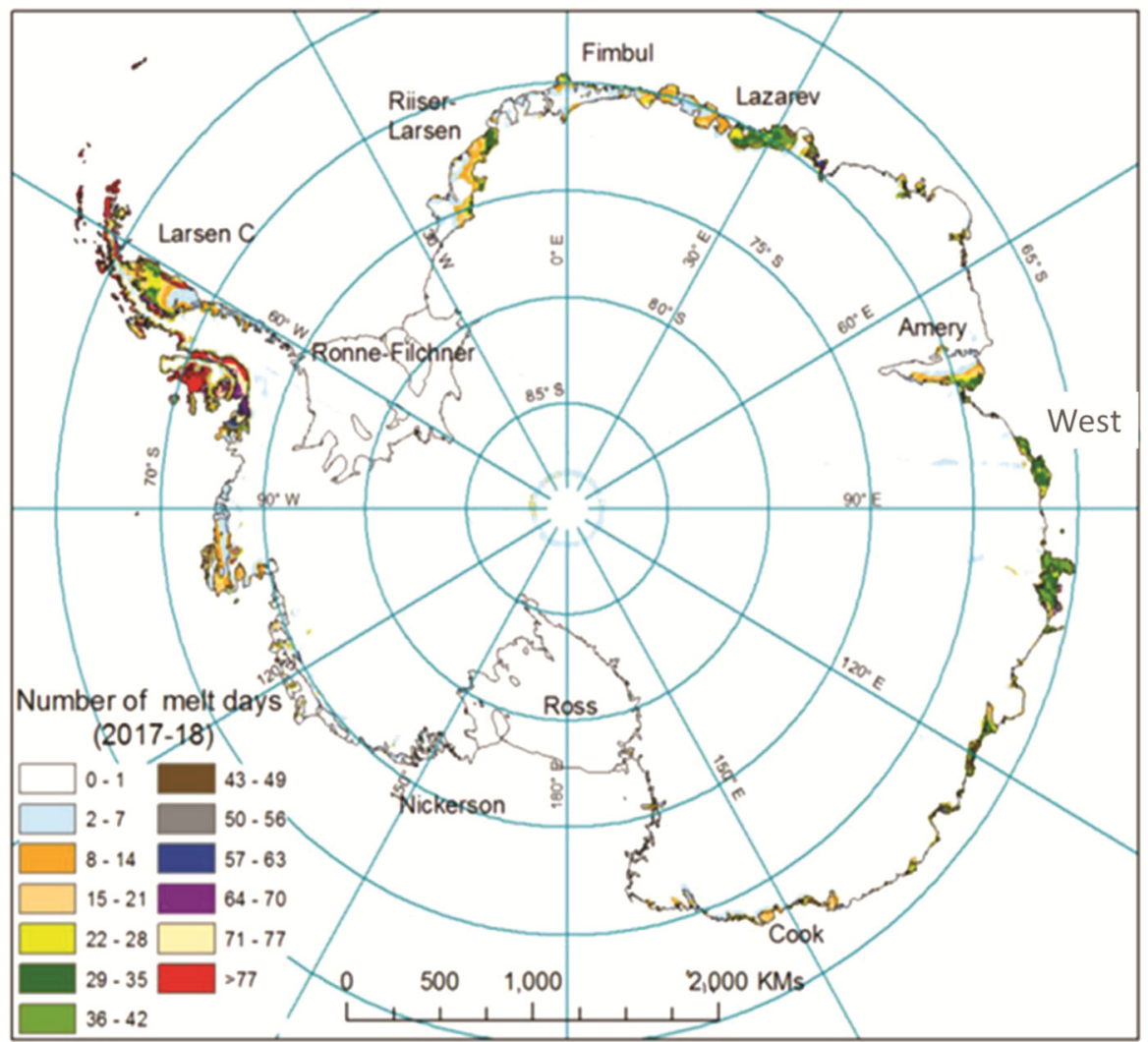

Figure 8. Spatial variation in the number of melt days (2017-18) observed using backscatter data.

hence it is dimensionless. $\mathrm{SWE}=\rho \mathrm{d}$, where $\rho$ is the density of snow, $d$ the snow depth, $\sigma_{g}^{0}$ is the scattering from the ground surface and short vegetation under the snowpack (Figure 2).

$A_{0}$ represents volume scattering from the snowpack when snow depth is much greater than the penetration depth, which is equal to $1 / k_{e}$, where $k_{e}$ is the extinction coefficient. $A_{0}$ and $C$ are constants derived from ground observations. If the bulk scattering properties of the snowpack do not change significantly with snow accumulation, the radar backscatter at two different times by $\sigma_{1}^{0}$ and $\sigma_{2}^{0}$ represents two different SWEs, viz. SWE1 and
SWE2 respectively. The constants $A_{0}$ and $C$ were calculated using the outputs generated from the calibrated variable infiltration capacity (VIC) $\operatorname{model}^{44,45}$ with $2.25 \mathrm{~km}$ resolution for Northwest Himalaya.

\section{Results and discussion}

\section{Temporal signature of ice features in the Antarctic}

SCATSAT- $1 \sigma^{0}$, gamma-0 and BT data provides information on different responses received from various cryospheric targets. Figure 3 shows false colour 


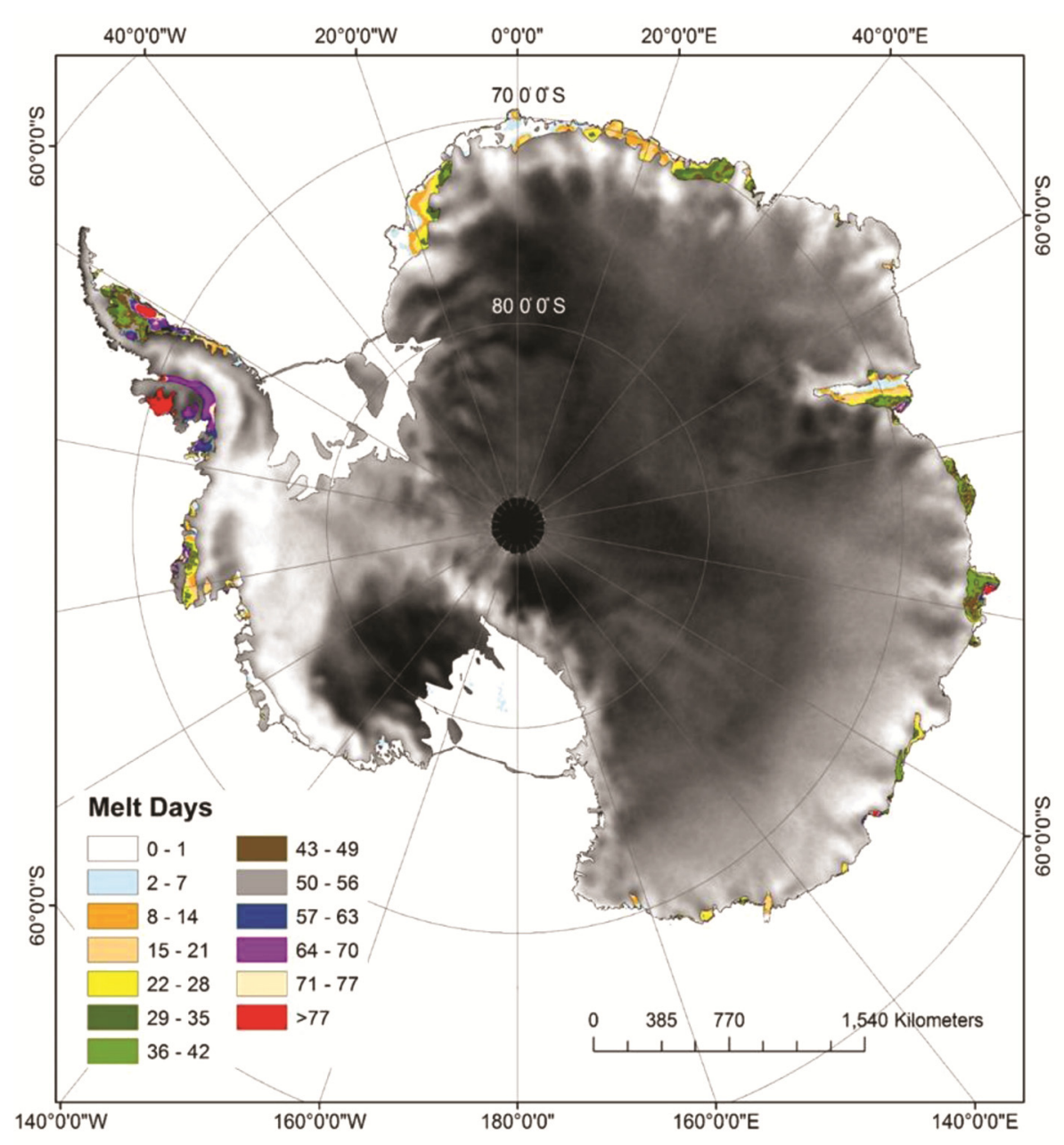

Figure 9. Number of melt days using brightness temperature values.

composite (FCC) image made from $\mathrm{BT}(H H)$ on red plane, gamma-0 $(V V)$ on green plane, while on the blue plane gamma- 0 active polarization ratio (APR) is displayed ${ }^{32}$.

The temporal variations of high-resolution gamma-0 products pertaining to various ice features/types was studied from 20 October 2016 to 16 May 2018. Figure 3 shows the locations of the selected ice features. The spatially averaged values of gamma- 0 for each day were computed for these ice features. Temporal variations for these features were studied in detail to understand the seasonal variations (Figure 4).

As seen from Figure 3, various sea-ice regions show variations in FCC. Other features like polynyas (open ocean/sea within sea-ice packs), snow dunes and ice shelves also give typical response in the SCATSAT-1 data. Interior area over the ice sheet around snow dunes (around point no. 1) also appears like ice shelves; however, ice shelves provide different temporal signatures (Figure 4) in contrast to interior ice sheets, and hence are separable in temporal domain.

As shown in Figure $4 a$, the backscatter response from Ross, Ronne and Amery ice shelves is different. Both
Ross and Ronne do not show the drastic changes in summer, whereas a dip in the gamma- 0 value prominent in summer (December-February) over Amery indicates melt. Ice-sheet behaviour is almost monotonous over the entire observation period in both $H H$ and $V V$. Both glaciers and icebergs, show smaller variations across seasons. Sea-ice region selected near the coast (point nos 6 and 8) also shows melting during summer, which forms the open ocean region surrounded by sea-ice, also known as polynya. Figure $4 b$ illustrates that polynya opening and closing can be shown by the variation in Gamma-0 in summer and winter. The gamma- 0 can also increase due to the presence of ice floe, which pass through the polynya due to ocean current and wind.

Figure 5 shows the temporal variations in gamma-0 values along the transect line $A B$ (inset) for the Larsen $\mathrm{C}$ ice shelf in the Antarctic Peninsular region. Here also the values are plotted at every two days and labelled at every 12 days. The line represents, at a particular pixel, the gamma- 0 value of each scan line along the transect. It is observed that the width of the curve in the middle of the line has increased continuously after 13 July 2017. 

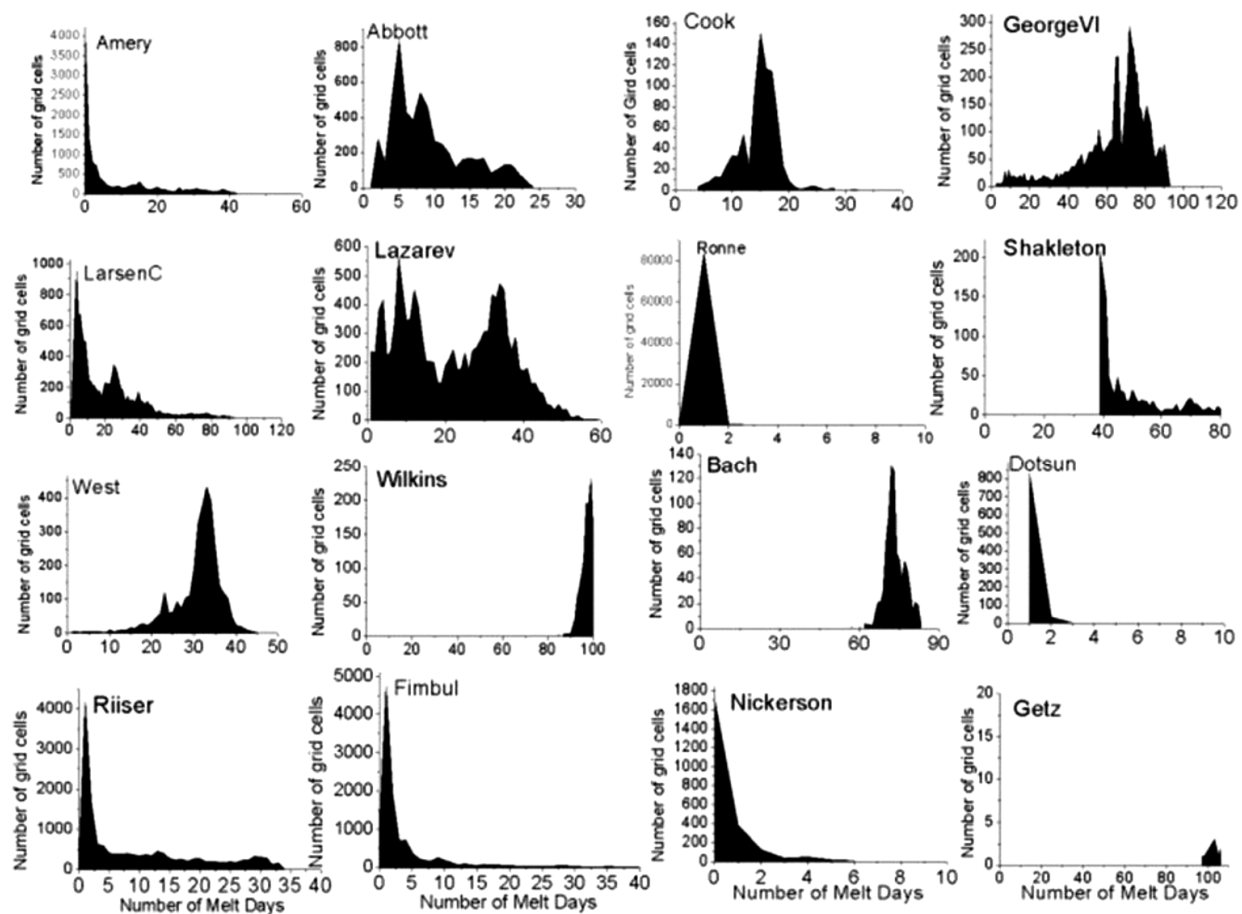

Figure 10. Shelf-wise variation in the number of melt days from backscatter data.

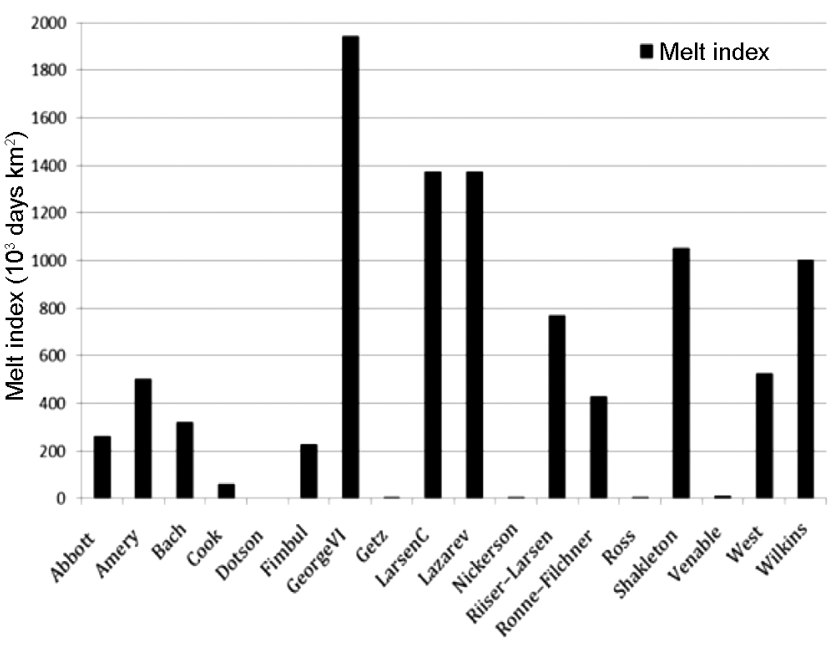

Figure 11. Melt index over different ice shelves in the Antarctic derived using backscatter data.

The backscatter dip width increases as the iceberg drifts away from the coast. The backscatter variations are attributed to the change in target characteristics from ice to ocean due to calving. This demonstrates the utility of high-resolution products for daily monitoring of the large-scale calving around Antarctica.

\section{Sea-ice monitoring}

Figure 6 shows the derived sea-ice image for 31 December 2017. Figure 7 shows the profile of daily sea-ice extent for 2017. As shown in Figure 7, the observed growth rate during autumn to winter (March onwards) is slower compared to the rapid ice loss observed during spring to summer (October onwards). Summer to winter increase in Antarctic sea ice during 2017 is from 2 million sq. $\mathrm{km}$ to just above 18 million sq. km. Antarctic continental ice-sheet area is of the order of $14 \mathrm{M}$ sq. $\mathrm{km}$; hence twofold increase in cryosphere area is observed in the Antarctic during winter period. For assessing the mapping accuracy of sea-ice images prepared using SCATSAT-1 L4 data, selected images of March 2017 were compared with the corresponding sea-ice images derived from AMSR2 ASI Sea-Ice Concentration (SIC) images $^{46}$. All the pixels having SIC higher than $15 \%$ are considered for the analysis. We found an overall sea-ice mapping accuracy of $89 \%$ over the Antarctic.

Melt/freeze assessment of Antarctic ice shelf: Using the criteria earlier for backscatter and BT, melt/freeze status was derived (Figures 8 and 9). Observed high-low pattern in both the images matches well. Three major Antarctic ice shelves in terms of area are Ross, FilchnerRonne and Amery. As observed in Figures 8 and 9, two larger ice shelves (Ross and Filchner-Ronne) have relatively cooler periods as number of melt days is negligible. Other researchers have also reported similar observations for different study periods ${ }^{10-12}$. Figure 10 shows the frequency distribution of melt days based on backscatter for selected ice shelves. Note that higher number of melt days is observed over the East Antarctic ice shelves, viz. Lazarev, West and Shakleton. 


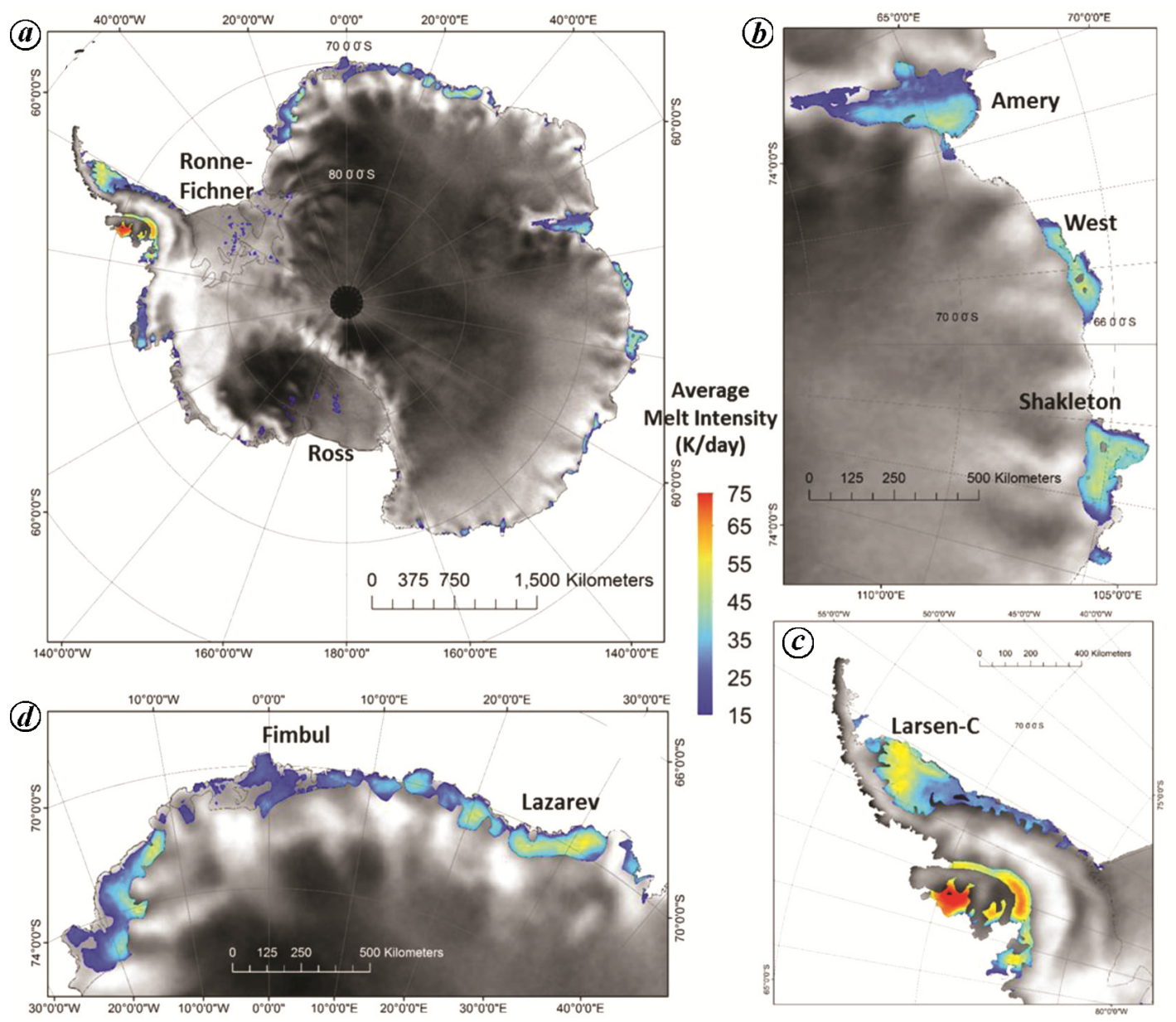

Figure 12. Average melt observed using BT data over (a) Antarctic ice shelves for the study period and regions covering (b) Amery ice shelf, (c) Antarctic Peninsula and (d) Fimbul ice shelf.

Figure 11 shows backscatter-based MI for the major ice shelves. The highest MI was observed over George VI shelf followed by Larsen $\mathrm{C}$ and Lazarev. Previous studies also showed similar patterns ${ }^{11,12}$. Highest MI for George VI was observed around 2200 during 2002-03 and 200607 (ref. 12), whereas in the present analysis it was found to be around 1950. Amery shelf continues to have low MI. This shelf was found to have the highest MI of around 2700 during the previous study ${ }^{12}$ conducted in 2004-05, but started a downwards trend after 2005. Around $36 \%$ area of the shelf has observed melt during the present study period.

Figure 12 shows AMI observed over the study region using BT data. As observed, large sized Ronne and Ross ice shelves (Figure 12a) show lower AMI compared to the relatively small-sized ice shelves like Larsen-C, West and Shackleton. This supports the findings of other researchers who studied melt using backscatter data ${ }^{11,12}$ or passive microwave data ${ }^{13}$. As observed in Figure $12 c$, ice shelves on the left and right side of Fimbul show higher AMI, despite relatively lower number of melt days. This could be due to the episodic events that take place during the study period, which contributed to the increase in average melt.

Amery is the third largest Antarctic ice shelf and largest in East Antarctica with a geographical area of about $60,000 \mathrm{sq} . \mathrm{km}$. As an ice shelf is the extended part of an ice sheet floating over the ocean, it is sensitive to changes in the atmospheric and oceanic parameters. The dense crevasse and rift which cover the lower half of the Amery ice shelf (Figure 12b) show higher surface melting compared to upper half using BT as well as backscatter data $^{47}$. Similar results were also observed using scatterometer data for the same region during previous study periods $^{11,12}$. Since BT response is not affected by surface roughness, observations confirm that it is only because of the dominated response from surface melt and eliminate the possible errors attributed to the contribution from rifts/crevasses.

Figure 13 shows spatial variations of surface melt observed over horizontal and vertical transects of Amery ice shelf. It can be seen that the value observed for transect B3 is much higher compared to that observed for transect B1. Cooler inner regions (transects A1 and A2) 


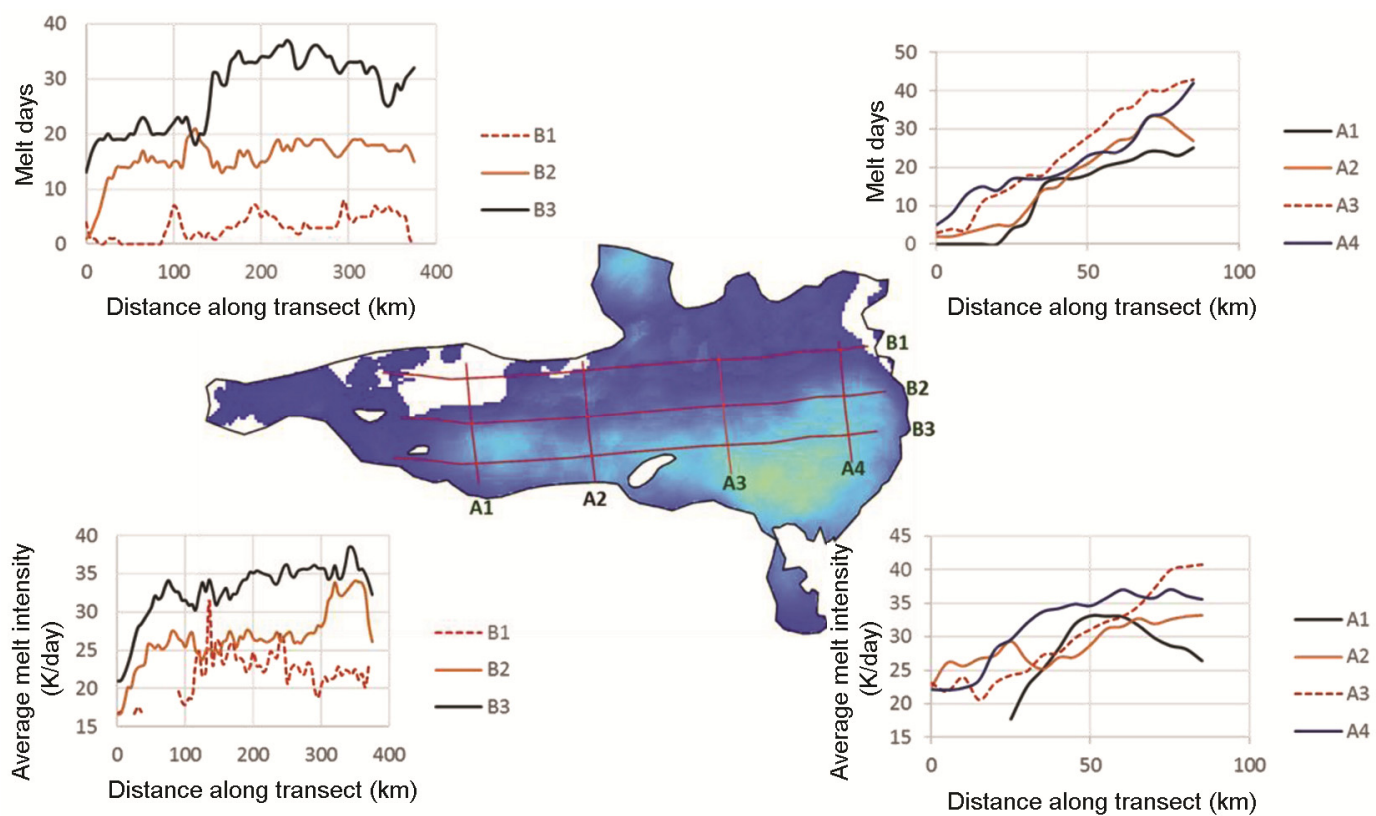

Figure 13. Spatial variations of BT-based surface melt observed over horizontal (B1-B3) and vertical (A1-A4) transects are shown in central figure. Variations observed in the number of melt days (see top left and top right figures) and average melt (see bottom left and bottom right figures) have been shown here.
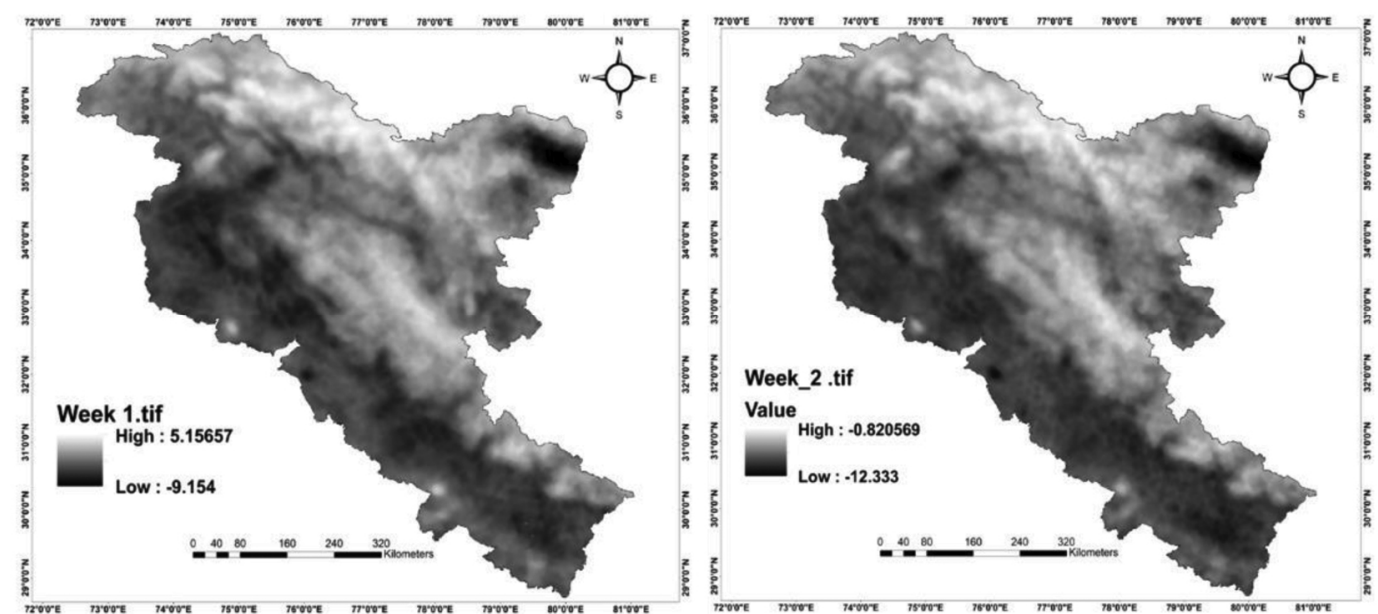

Figure 14. $\sigma^{0}$ images derived from level 4, version 1.1.2 raw dataset of SCATSAT-1 for the first and second week of January 2017 for the Northwest Himalaya.

and warmer frontal regions (transects A3 and A4) are also observed in the figure. This shows the typical behaviour of surface melting over Amery ice shelf, with highest melting observed in the lower right (front facing) region. This region is full of crevasses and rifts and penetration of surface melt water triggers the propagation of rifts $^{9}$, which affects the stability of the ice shelf.

\section{Estimation of snow water equivalent over North West Himalaya}

Figure 14 shows $\sigma^{0}$ images of SCATSAT- 1 for the first and second week of January 2017 covering Northwest
Himalaya. As observed, the maximum and minimum backscatter has decreased significantly in the second week of January 2017 as a result of change in SWE.

In Figure 15, negative values show decrease in SWE and positive value show increase in SWE. This change $(\triangle \mathrm{SWE})$ can occur due to various processes such as snowfall, snowmelt and snow metamorphism within the snowpack. The observed SWE (calibrated VIC model output) and calculated SWE from change detection algorithm show fairly good correlation between observed and calculated $\triangle \mathrm{SWE}$. This is observed from the values of $R^{2}$ and Nash-Sutcliffe (NS) coefficients (Figure 16). The present study demonstrates the usefulness of SCATSAT-1 


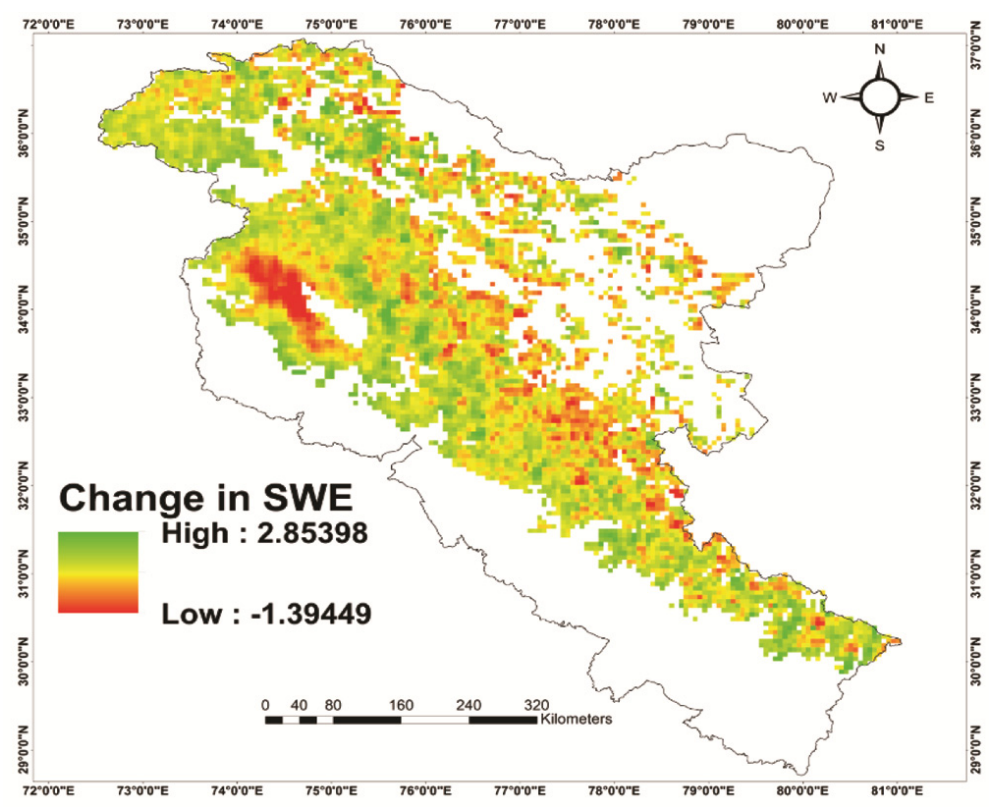

Figure 15. Change in SWE $(\mathrm{cm})$ calculated for the first to second week of January 2017 by deriving constants $A_{0}$ and $C$ from ground-observed data using calibrated VIC model.

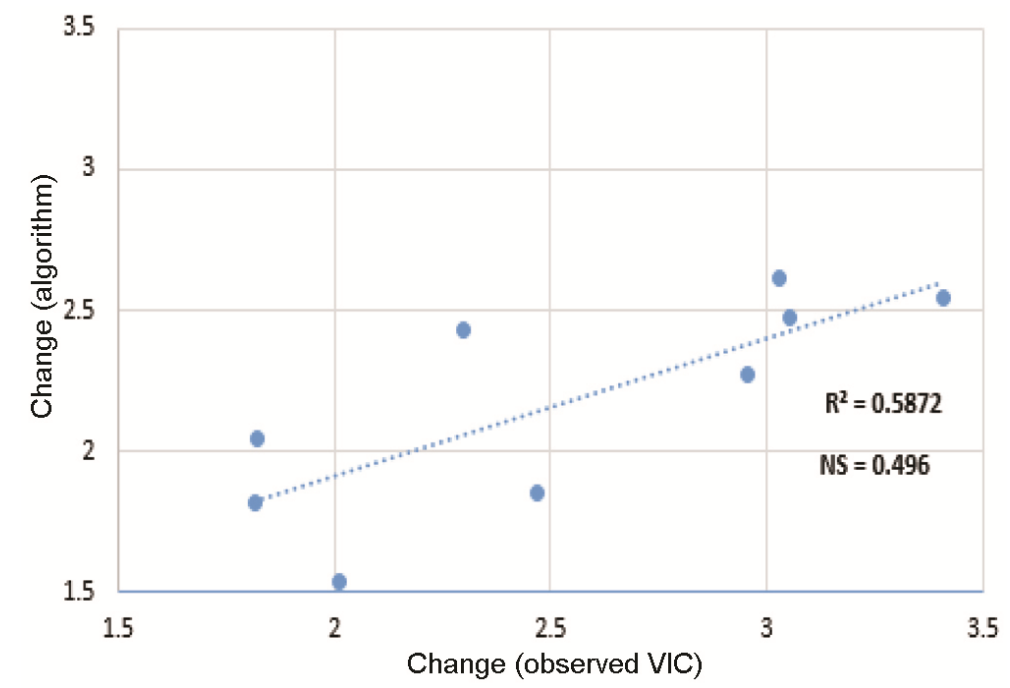

Figure 16. Validation results for different locations in Northwest Himalaya for observed (VIC) versus calculated $\triangle \mathrm{SWE}$ for the first and second week of January 2017.

datasets in retrieval of change in SWE using the proposed method. This method needs further improvement by incorporating more ground-based $\triangle \mathrm{SWE}$, snow depth datasets, etc. In addition, this method can be modified to obtain the total SWE by integrating $\triangle \mathrm{SWE}$ with base SWE, which can be taken from calibrated land surface models or ground-based SWE datasets.

\section{Conclusion}

Unique advantages of availability of passive BT and active backscatter data were utilized in assessing changes observed over the Antarctic cryospheric region. Intraannual variations observed in the gamma-0 time series help to understand the seasonal variations and changes occurring around the calving event. A procedure developed for estimation of sea-ice extent using BT, gamma-0 and polarization difference property has been demonstrated for monitoring daily Antarctic sea-ice extent year 2017. Comparison with passive microwave-based reference product suggests an overall accuracy of $89 \%$.

Backscatter and BT based derivation of surface melting for summer period of 2017-18 over the entire belt of ice shelves bordering Antarctica has revealed some interesting 
results. It was observed that majority of East Antarctic ice shelves show higher surface melting, despite relatively lower number of melt days. This is suggestive of the contribution from extreme episodic warming events. The third largest Antarctic ice shelf, Amery located near the Indian Antarctic research station 'Bharati' shows typical spatially varying pattern of surface melting over the west-east and south-north transects. Extreme melt observed over the northeastern portion is as high as that observed over West Antarctic Larsen-C ice shelf. The study shows that the East Antarctic ice shelves are also prone to warming phenomenon that may contribute to the ice-shelf instability. The change in SWE can be derived using backscatter change detection technique, which uses one-layer radiative transfer equation. SWE is required in various applications such as flood forecasting, controlling the water level of power plant reservoirs, planning for forestry and crop irrigation, and as input and control variable for environmental research purposes, including climate change research. The present study demonstrates the application potential of SCATSAT-1 data for the assessment of cryospheric parameters such as SWE and ice surface melt, sea-ice extent and in detecting the changes around Antarctic ice margins.

1. Vaughan, D. G. et al., Observations: cryosphere. In Climate Change 2013: The Physical Science Basis. Contribution of Working Group I to the Fifth Assessment Report of the Intergovernmental Panel on Climate Change (eds Stocker, T. F. et al.), Cambridge University Press, Cambridge, UK, 2013, pp. 317382.

2. Lieser, J. L. et al., Position Analysis: Antarctic Sea Ice and Climate Change 2014, Antarctic Climate \& Ecosystems Cooperative Research Centre, Hobart, Tasmania, Australia, 2013, ISBN 978-0646-91260-8

3. Rivas, M. B. and Stoffelen, A., New Bayesian algorithm for seaice detection with QuikSCAT. IEEE Trans. Geosci. Remote Sensing, 2011, 49(6), 1894-1901; doi:10.1109/TGRS.2010.2101608.

4. Comiso, J. C., Gersten, R. A., Stock, L. V., Turner, J., Perez, G. J. and Cho, K., Positive trend in the Antarctic sea-ice cover and associated changes in surface temperature. J. Climate, 2017, 30, 2251-2267; doi:10.1175/JCLI-D-16-0408.1.

5. Yuan, N., Ding, M., Ludescher, J. and Bunde, A., Increase of the Antarctic sea-ice extent is highly significant only in the Ross Sea. Sci. Rep., 2017, 7, 41096; doi:10.1038/srep41096.

6. Santis, A. D., Maier, E., Gomez, R. and Gonzalez, I., Antarctica, 1979-2016 sea-ice extent: total versus regional trends, anomalies and correlation with climatological variables. Int. J. Remote Sensing, 2017, 38, 7566-7584.

7. Turner, J. et al., Antarctic climate change during the last 50 years. Int. J. Climatol., 2005, 25, 279-294.

8. Trusel, L. D., Frey, K. E. and Das, S. B., Antarctic surface melting dynamics: enhanced perspectives from radar scatterometer data. J. Geophys. Res., 2012, 117, F02023; doi:10.1029/2011JF002126.

9. Oza, S. R., Spatial-temporal patterns of surface melting observed over Antarctic ice shelves using scatterometer data. Antarct. Sci., 2015, 27, 403-410.

10. Bothale, R. V., Rao, P. V. N., Dutt, C. B. S., Dadhwal, V. K. and Maurya, D., Spatio-temporal dynamics of surface melting over Antarctica using OSCAT and QuikSCAT scatterometer data (2001-2014). Curr. Sci., 2015, 109, 733-744.
11. Wang, X, Wang, C. and Li, B., Spatiotemporal analysis of Antarctic snowmelt changes using microwave radiometer data (19782015). Fresesius Environ. Bull., 2018, 3028-3034.

12. Hock, R., Rees, G., Williams, M. W. and Ramirez, E., Preface contribution from glaciers and snow cover to runoff from mountains in different climates. Hydrol. Process., 2006, 20, 2089-2090.

13. Takala, M. et al., Estimating northern hemisphere snow water equivalent for climate research through assimilation of spaceborne radiometer data and ground- based measurements, Remote Sensing Environ., 2011, 115, 3517-3529.

14. Sturm, M. and Liston, G. E., The snow cover on lakes of the Arctic coastal plain of Alaska, USA. J. Glaciol., 2003, 49, 370-380.

15. Ridley, J., Surface melting on Antarctic Peninsula ice shelves detected by passive microwave sensors. Geophys. Res. Lett., 1993, 23, 2639-2642; doi:10.1029/93GL02611.

16. Kunz, L. B. and Long, D. G., Melt detection in Antarctic ice shelves using scatterometers and microwave radiometers. IEEE Trans. Geosci. Remote Sensing, 2006, 44, 2461-2469.

17. Liu, H., Wang, L. and Jezek, K. C., Spatiotemporal variations of snowmelt in Antarctica derived from satellite scanning multichannel microwave radiometer and Special Sensor Microwave Imager data (1978-2004). J. Geophys. Res., 2006, 111, F01003; doi:10.1029/2005JF000318.

18. Picard, C. and Fily, M., Surface melting observations in Antarctica by microwave radiometers: correcting 26-year time series from changes in acquisition hours. Remote Sensing Environ., 2006, 104, 325-336.

19. Tedesco, M., Assessment and development of snowmelt retrieval algorithms over Antarctica from K-band spaceborne brightness temperature (1979-2008). Remote Sensing Environ., 2009, 113, 979-997.

20. Oza, S. R., Singh, R. K. K., Vyas, N. K., Gohil, B. S. and Sarkar, A., Spatio-temporal coherence based technique for near-real time sea-ice identification from scatterometer data. J. Indian Soc. Remote Sensing, 2010, 39, 169-176.

21. Bothale, R. V., Rao, P. V. N., Dutta, C. B. S. and Dadhwal, V. K., Dynamics of surface melting over Amery and Ross ice shelf in Antarctic using OCAT data. Int. Arch. Photogramm., Remote Sensing Spat. Inf. Sci., 2014, XL-8, 505-509; doi:10.5194/ isprsarchives-XL-8-505-2014.

22. Cavalieri, D. J., Gloersen, P. and Campbell, W. J., Determination of sea-ice parameters with the Nimbus 7 SMMR. J. Geophys. Res., 1984, 89, 5355-5369.

23. Cavalieri, D. J., Crawford, J., Drinkwater, M. R., Eppler, D. T., Farmer, L. D., Jentz, R. R. and Wackerman, C., Aircraft active and passive microwave validations of sea-ice concentrations from the DMSP SSM/I. J. Geophys. Res., 1991, 96, 21989-22008.

24. Zwally, H. J., Comiso, J. C., Parkinson, C. L., Campbell, W. J., Carsey, F. D. and Gloersen, P., Antarctic sea-ice, 1973-1976: satellite passive microwave observations, National Aeronautics and Space Administration, Washington, DC (NASA SP 459), 1983.

25. Parkinson, C. L., Comiso, J. C., Zwally, H. J., Cavalieri, D. J., Gloersen, P. and Campbell, W. J., Arctic sea ice 1973-1976 from satellite passive microwave observations. NASA Special Publication No. 489, 1987.

26. Comiso, J. C., Cavalieri, D. J., Parkinson, C. L. and Gloersen, P., Passive microwave algorithms for sea-ice concentration: a comparison of two techniques. Remote Sensing Environ., 1997, 60, $357-384$.

27. Vyas, N. K. and Dash, M. K., Oceansat-MSMR observes interesting features on the frozen continent and surrounding sea. J. Indian Soc. Remote Sensing, 2000, 28, 67.

28. Vyas, N. K., Dash, M. K., Bhandari, S. M., Khare, N., Mitra, A. and Pandey, P. C., Large-scale Antarctic features captured by Multi-Frequency Scanning Microwave Radiometer onboard Oceansat-1. Curr. Sci., 2001, 80, 1319-1322.

29. Dash, M. K., Bhandari, S. M., Vyas, N. K., Khare, N., Mitra, A. and Pandey, P. C., Oceansat-MSMR imaging of the Antarctic and 
the Southern Polar Ocean. Int. J. Remote Sensing, 2001, 22, $3253-$ 3259.

30. Bhandari, S. M., Dash, M. K., Vyas, N. K., Khare, N. and Pandey, P. C., Microwave remote sensing of sea-ice in the Antarctic region from Oceansat-1 MSMR. In Advances in Marine and Polar Science (eds Sahoo, D. and Pandey, P. C.), A.P.H. Publishing Corporation, New Delhi, 2002.

31. Bhandari, S. M., Vyas, N. K., Dash, M., Shrama, N. and Pandey, P. C., Simultaneous MSMR and SSM/I observations and analysis of sea-ice characteristics over the Antarctic region. Int. J. Remote Sensing, 2005, 26, 3123-3136.

32. Haarpaintner, J., Tonboe, R. T. and Long, D. G., Automatic detection and validity of the sea-ice edge: an application of enhancedresolution QuikSCAT/SeaWinds data. IEEE Trans. Geosci. Remote Sensing, 2004, 42(7), 1433-1443; doi:10.1109/ TGRS.2004.828195.

33. Oza, S. R., Singh, R. K. K., Vyas, N. K. and Sarkar, A., Recent trends of Arctic and Antarctic summer sea-ice cover observed from space-borne scatterometer. J. Indian Soc. Remote Sensing, 2010, 38, 611-616.

34. Rivas, M. B., Otosaka, I., Stoffelen, A. and Verhoef, A., A scatterometer record of sea-ice extents and backscatter: 1992-2016. Cryosphere Discuss, 2018, doi:10.5194/tc-2018-68.

35. Li, M., Zhao, C., Zhao, Y., Wang, Z. and Shi, L., Polar sea-ice monitoring using HY-2A scatterometer measurements. Remote Sensing, 2016, 8, doi:10.3390/rs8080688.

36. Singh, R. K., Singh, K. N., Maisnam, M., Jayaprasad, P. and Maity, S., Antarctic sea-ice extent from ISROs SCATSAT-1 using PCA and an unsupervised classification. In Proceedings of the 2nd International Electronic Conference on Remote Sensing (ECRS2), 2018, 2, doi:10.3390/ecrs-2-05153.

37. Lindell, D. B. and Long, D. G., Multiyear Arctic ice classification using ASCAT and SSMIS. Remote Sensing, 2016, 8, doi:10.3390/rs8040294.

38. Rajak, D. R., Singh, R. K. K., Jayaprasad, P., Oza, S. R., Sharma, R. and Raj Kumar, Sea ice occurrence probability data and its applications over the Antarctic. J. Geomat., 2015, 9, 193-197.

39. Ulaby, F. T., Moore, R. K. and Fung, A. K., Microwave Remote Sensing-Active and Passive, Vol. III: From Theory to Applications, Artech House, Dedham, MA, USA, 1986.

40. Wismann, V., Monitoring of seasonal snowmelt on Greenland with ERS scatterometer data. IEEE Trans. Geosci. Remote Sensing, 2000, 38, 1821-1826.
41. Smith, L. C., Sheng, Y., Forster, R. R., Steffen, K., Frey, K. E. and Alsdorf, D. E., Melting of small Arctic caps observed from ERS scatterometer time series. Geophys. Res. Lett., 2003, 30, doi:10.1029/2003GL017641.

42. Oza, S. R., Singh, R. K. K, Vyas, N. K. and Sarkar, A., Study of inter-annual variations in surface melting over Amery Ice Shelf, East Antarctica using space-borne scatterometer data. J. Earth Syst. Sci., 2011, 120, 329-336.

43. Yueh, S., Cline, D. and Elder, K., POLSCAT Ku-band radar remote sensing of terrestrial snow cover. In IGARSS $2008-2008$ IEEE International Geoscience and Remote Sensing Symposium, 2008; doi:10.1109/IGARSS.2008.4779276.

44. Liang, X., Lettenmaier, D. P., Wood, E. F. and Burges, S. J., A simple hydrologically based model of land surface water and energy fluxes for GSMs. J. Geophys. Res., 1994, 99(D7), 1441514428.

45. Aggarwal, S. P., Garg, V., Gupta, P. K., Nikam, B. R., Thakur, P. K. and Roy, P. S., Runoff potential assessment over Indian landmass: a macro-scale hydrological modeling approach. Curr. Sci., 2013, 104(7), 950-959.

46. Spreen, G., Kaleschke, L. and Heygster, G., Sea ice remote sensing using AMSR-E $89 \mathrm{GHz}$ channels. J. Geophys. Res., 2008, 113, C02S03; doi:10.1029/2005JC003384.

47. Simone, S., Oza, S. R., Shah, R. D., Rathore, B. P. and Bahuguna, I. M., Rift assessment and potential calving zone of Amery Ice Shelf, East Antarctica. Curr. Sci., 2018, 115(9), 1799-1804.

ACKNOWLEDGEMENTS. We thank the Directors of Space Applications Centre (SAC), National Remote Sensing Centre (NRSC) and Indian Institute of Remote Sensing (IIRS) for encouragement and support; Dr Raj Kumar (Deputy Director, EPSA/SAC) for guidance and Dr A. S. Rajawat (SAC), Dr Arundhati Misra (SAC), Dr S. P. Aggarwal (IIRS) and Shri Deepak Putrevu (SAC) for their valuable suggestions. We also thank Shri Suvrat Kaushik (IIRS), Ms Pooja Mishra (M. G. Science Institute) and Ms Mehanaz Fathima (NRSC) for help during the analysis and Dr Sushil Kumar Singh (SAC) and Shri B. P. Rathore (SAC) for useful suggestions.

doi: $10.18520 / \mathrm{cs} / \mathrm{v} 117 / \mathrm{i} 6 / 1002-1013$ 